\title{
Phytochemical Screening and Antioxidant Activity of Origanum majorana Against Oxidative Stress Biomarkers
}

\author{
Regis Augusto Norbert Deuschle ${ }^{1}$, Viviane Cecília Kessler Nunes Deuschle ${ }^{1}$, Gabriela Bonfanti-Azzolin ${ }^{2}$, \\ Juliana Sorraila de Oliveira ${ }^{3}$, Queli Cristina Bitencourt Sostisso ${ }^{3}$, Jéssica dos Santos Goulart ${ }^{3}$, \\ Mariana Spanamberg Mayer ${ }^{3}$, Roberta Cattaneo Horn ${ }^{2,3,4}$ \& Diego Pascoal Golle ${ }^{4,5}$ \\ ${ }^{1}$ Programa de Pós-Graduação em Ciências Farmacêuticas, Centro de Ciências da Saúde, Universidade Federal \\ de Santa Maria, Brazil \\ ${ }^{2}$ Programa de Pós-Graduação em Atenção Integral a Saúde, Universidade de Cruz Alta e Universidade do \\ Noroeste do Rio Grande do Sul, Brazil \\ ${ }^{3}$ Laboratório de Plantas Medicinais e Estresse Oxidativo, Universidade de Cruz Alta, Cruz Alta, RS, Brazil \\ ${ }^{4}$ Mestrado Profissional em Desenvolvimento Rural, Universidade de Cruz Alta, Cruz Alta, RS, Brazil \\ ${ }^{5}$ Laboratório de Cultivo In vitro, Universidade de Cruz Alta, Cruz Alta, RS, Brazil \\ Correspondence: Roberta Cattaneo Horn, Universidade de Cruz Alta, Campus Universitário Dr. Ulisses \\ Guimarães, Rod. Municipal Jacob Della Méa, km 5.6, Parada Benito, 98020-290, Cruz Alta, RS, Brazil. E-mail: \\ rcattaneo@unicruz.edu.br
}

Received: August 2, 2018

doi:10.5539/jas.v10n12p395
Accepted: September 16, $2018 \quad$ Online Published: November 15, 2018

URL: https://doi.org/10.5539/jas.v10n12p395

\begin{abstract}
Origanum majorana is a cosmopolitan herb widely known as "marjoram", which is used in traditional medicine and as family kitchen herb, for culinary purposes. Phytochemical screening was carried out and the antioxidant activity of Origanum majorana (Lamiaceae) hydroethanolic extract and infusion was investigated in this study. The hydroethanolic extract was screened through thin layer chromatography, subjected to spectrophotometry for polyphenols, flavonoids and tannins, as well as to 2,2-diphenyl-1-picrylhydrazyl free radical and iron reducing power assays. Fresh plant infusion was tested for the first time at three different concentrations against oxidative stress biomarkers in erythrocytes from HIV patients undergoing antiretroviral therapy. High antioxidant substance levels, as well as significant decrease in carbonylated protein, GSH and TBARS levels, were recorded, fact that showed the potential of $O$. majorana as exogenous antioxidant source. Our results indicated that $O$. majorana has good potential to prevent diseases caused by the overproduction of free radicals, and that it can be used as potential source of natural antioxidant agents.
\end{abstract}

Keywords: antioxidant activity, erythrocytes, HIV virus, oxidative stress

\section{Introduction}

Origanum majorana belongs to family Lamiaceae and is a cosmopolitan herb widely known as "marjoram". It is used in traditional medicine to treat gastro-intestinal disorders, depression, dizziness, migraine, paroxysmal cough, besides being used in several countries due to its diuretic and anti-coagulant properties (Yazdanparast \& Shahriyary, 2008). It is also a family kitchen herb widely used for culinary purposes such as seasoning in salads (Park, 2011; Hafez, 2012).

Among its phytochemical constituents, the literature has shown that its volatile oil has terpinen-4-ol and $(+)$-cis-sabinene, which are responsible for the characteristic flavor and aroma of its essence. Although terpinolenes (a- and g-), thymol and carvacrol were also reported as majoritary compounds, there can be composition variations, mainly between samples from different locations (Novak, Langbehn, Pank, \& Franz, 2002; Edris, Shalaby, \& Fadel, 2003). Other secondary metabolites such as rosmarinic acid, methyl rosmarinate, apigenin and luteolin-7-O-rutinosis (Shan, Cai, Sun, \& Corke, 2005; Wojdylo, Oszmianski, \& Czemerys, 2007; Roby, Sarhan, Selim \& Khalel, 2013) were also found in methanolic extracts.

Among the biological activities previously reported for marjoram, one finds cardioprotection against myocardial infarction (Ramadan, El-Beih, Arafa, \& Zahra, 2013), cell adhesion inhibition, protein secretion and platelet 
self-aggregation (Yazdanparast \& Shahriyary, 2008), apoptotic and anti-proliferative activities in leukemic lymphoblastoid Jurkat T-cells (Abdel-Massih, Fares, Bazzi, El-Chami, \& Baydoun, 2010) and gastroprotection against ulcers (Pimple, Kadam, \& Patil, 2012).

Health hazards resulting from damages caused by oxidative stress are well known, for example: the excessive production of oxygen and nitrogen free radicals. The production of these substances under such conditions exceeds the quenching capacity of antioxidant enzyme (such as superoxide dismutase, glutathione peroxidase and catalase) and non-enzymatic systems (such as glutathione, ascorbic acid and $\alpha$-tocopherol), thus leading to cell damage and, subsequently, to health issues (Bhatia, Shukla, Madhu, Gambhir, \& Prabhu, 2003; Peuchant et al., 2004). In these cases, it is necessary adopting supplementation with exogenous antioxidants to help re-establishing the redox state at homeostatic level. A previous study demonstrated the potential of $O$. majorana $\times$ O.vulgare to enhance the oxidative stability of eggs rich in omega 3 fatty acids (Handl et al., 2008). A study conducted with cakes supplemented with different marjoram concentrations demonstrated its effective antioxidant properties (Hafez, 2012). In addition, studies have shown that culinary herbs and spices can work as bioactive polyphenol sources and have beneficial effects on human health. Among their main properties, we highlight antioxidant, anti-inflammatory and anticarcinogenic activities, which could be related to their polyphenolic content (Elansary et al., 2018, Oniga et al., 2018).

Given the usefulness of natural products as possible sources of dietary antioxidants, $O$. majorana L. was herein selected as object of study by taking into consideration its use as spice in food. Samples were subjected to phytochemical screening and their antioxidant activity against oxidative stress biomarkers was investigated.

\section{Methods}

\subsection{Chemical Reagents, Apparatus and General Procedures}

All chemical reagents were of analytical grade. Hexane and ethanol were purchased at Vetec. Methanol; acetic acid, gallic acid, chlorogenic acid, caffeic acid, ascorbic acid, ferric chloride and aluminum thin layer chromatography (TLC) plates were purchased at Merck (Darmstadt, Germany); 2,4,6-tripyridyl-S-triazine and rutin were purchased at Sygma. Spectrophotometric measurements were performed in a Shimadzu UV-120 spectrophotometer (Shimadzu, Kyoto, Japan).

\subsection{Plant Material}

Plant material comprised fresh Origanum majorana L leaves, which were manually harvested in the urban area of Cruz Alta County (mean altitude 452 meters, latitude 28 $38^{\prime} 19^{\prime \prime}$ South and longitude 5336'23" West), Rio Grande do Sul State, Brazil. Voucher specimen was identified by botanist Diego Pascoal Golle and registered under the number 1098 at the Herbarium of Medicinal and Toxic Plants, University of Cruz Alta.

\subsubsection{Hydroethanolic Extract and Infusion Obtainment}

Fresh $O$. majorana leaves were dried in oven under air circulation, at $45^{\circ} \mathrm{C}$, for 3 days. Dried leaves were reduced to powder in a knife mill. Lipophilic substances were previously removed by maceration using hexane at room temperature, at solvent:plant ratio 9:1. Ten (10) days later, the liquid phase was filtered and the process was repeated. Next, the plant powder was covered with hydroethanolic mixture (ethanol:water, 70:30, v/v) based on the same procedure described above. Ethanol from the filtrate was subjected to evaporation under reduced pressure. Then, the resulting material was dried by lyophilization and the resulting product was named hydroethanolic extract (HET).

Origanum majorana infusion (OMINF) was obtained by heating $100 \mathrm{~mL}$ of water to the boiling point in a closed container. Heating was turned off after the boiling point was reached and the container was uncovered to allow the addition of 5.0 grams of fresh plant. Next, it was closed again for 10 minutes. Then, filtration was carried out in order to obtain an infusion at $50 \mathrm{~g} / \mathrm{L}$ concentration, which was diluted to reach concentrations 25 and $10 \mathrm{~g} / \mathrm{L}$.

\subsubsection{Phytochemical Screening}

Both extracts were subjected to phytochemical screening through thin layer chromatography (TLC) in order to find the essential oil components, terpenoids, saponins and alkaloids (Wagner \& Bladt, 1996). The solid phase consisted of aluminum TLC plates coated with silica-gel 60 and $F_{254}$ fluorescent indicator. Mobile phases consisted of specific solvent mixtures for each substance class, as shown in Table 1. Post-elution samples were observed under UV 254 and $365 \mathrm{~nm}$, and under visible light after they were sprayed with specific indicators.

(1) Polyphenol, Total Flavonoid and Condensed Tannin Determination

Total polyphenol content was investigated based on the Folin-Ciocalteau method (Chandra \& De Mejia, 2004) using $0.15 \mathrm{mg} / \mathrm{mL}$ HET solutions. Absorbance was measured in spectrophotometer at wavelength $730 \mathrm{~nm}-$ 
measurements were conducted in triplicate. Total polyphenol content was expressed as milligrams of gallic acid equivalents per gram of dry plant. The equation applied to the standard gallic acid curve was $\mathrm{y}=52.167 \mathrm{x}-0.0631$ $(\mathrm{r}=0.9999)$.

Total flavonoid content was spectrophotometrically analyzed (Woisky \& Salatino, 1998), $0.5 \mathrm{~mL}$ of $\mathrm{AlCl}_{3}$ solution at $2 \%$ was added to $1 \mathrm{~mL}$ HET $(150 \mu \mathrm{g} / \mathrm{mL})$; absorbances were read at $420 \mathrm{~nm}, 15$ minutes later. Tests were performed in triplicate. The equation applied to the standard quercetin curve was $y=0.0045 x-0.014(r=0.9997)$. Flavonoid content was expressed as milligrams of quercetin equivalents per gram of dry plant.

Tannin content was spectrophotometrically determined (Morrison, Asiedu, Stuchbury, \& Powel, 1995) using HET samples at concentration $0.25 \mathrm{mg} / \mathrm{mL}$, as well as $5 \mathrm{~mL}$ of solutions $\mathrm{A}$ ( $1 \mathrm{~g}$ vanillin in $100 \mathrm{~mL}$ methanol) and B (8 $\mathrm{mL} \mathrm{HCl}$ in $100 \mathrm{~mL}$ methanol). Samples were read at $500 \mathrm{~nm}$. Total tannin was expressed as milligrams of catechin equivalents per gram of dry plant. The equation applied to the standard catechin curve was $\mathrm{y}=0.00015 \mathrm{x}-0.005(\mathrm{r}$ $=0.9989)$. Experiments were performed in triplicate.

\section{(2) Free Radical Scavenging Activity and Reducing Power}

Free radical scavenging activity was evaluated through the DPPH spectrophotometric method (Choi et al., 2002), using HET concentrations 250, 125, 62.5, 31.25, 15.62 and $7.81 \mu \mathrm{g} / \mathrm{mL}$. Then, $2.5 \mathrm{~mL}$ of each sample was added with $1.0 \mathrm{~mL}$ of $0.3 \mathrm{mM}$ DPPH solution in ethanol and incubated in dark chamber for 30 minutes - readings were performed at $518 \mathrm{~nm}$. DPPH solution $(1 \mathrm{~mL}, 0.3 \mathrm{mM})$ in ethanol $(2.5 \mathrm{~mL})$ was used as negative control, whereas standard ascorbic acid and rutin solutions (at concentrations equal to that of samples) were used as positive controls. Solutions of each test sample without DPPH addition were used as blank. Tests were performed in triplicate and antioxidant activity was calculated based on the equation below:

$$
\text { Radical scavenging activity }(\%)=100-[(\text { Abs sample }- \text { Abs blank }) / \text { Abs control } \times 100]
$$

Where, Abs sample = sample absorbance; Abs blank = blank absorbance; Abs Control = ethanolic DPPH solution absorbance.

Ferric reducing antioxidant power (FRAP) assay was used to determine the reducing power of the extract at concentrations $25,50,100,250,500$ and $1000 \mu \mathrm{g} / \mathrm{mL}$; gallic acid was used as standard and expressed as $\mu \mathrm{M}$ $\mathrm{Fe}^{2+} / \mathrm{mL}$ extract (Benzie \& Strain, 1996).

\subsubsection{Statistical Analysis}

Results were used to generate an inhibition rate versus extract concentration graph. Scavenging, or inhibitory, concentration (IC 50) was defined as the extract concentration $(\mu \mathrm{g} / \mathrm{mL})$ required to inhibit $50 \%$ of the DPPH in the assay medium; it was calculated in the Microsoft Office Excel 2007® software based on the standard curve. Each value was expressed as mean \pm standard error of the mean, $n=3$. Different letters were significantly different at $p$ $<0.05$. Data were subjected to analysis of variance, which was followed by Tukey's multiple comparison post-hoc test.

\subsection{Analyzing the Antioxidant Capacity of Origanum marjorana Infusion (OMINF) Through Oxidative Stress Biomarkers in Erythrocytes of HIV-Positive Individuals}

Biological material from seventeen random male and female HIV patients undergoing antiretroviral therapy was collected through venipuncture by using vacuum tubes containing ethylenediaminetetraacetic acid (EDTA). The biological material was homogenized and packed in thermal boxes after collection. Subsequently, samples were centrifuged at $3000 \mathrm{rpm}$ for 10 minutes and the plasma was removed. Erythrocytes were washed three times with isotonic saline solution and diluted in $0.9 \%$ saline solution until reaching 5\% hematocrit (Horn et al., 2015). The post-dilution supernatant was discarded and the erythrocytes of each participant were divided in four treatment groups:

Basal (OMINF free): Erythrocytes from HIV individuals treated with saline solution;

Group 10: Erythrocytes from HIV individuals treated with OMINF at $10 \mathrm{~g} / \mathrm{L}$;

Group 25: Erythrocytes from HIV individuals treated with OMINF at $25 \mathrm{~g} / \mathrm{L}$;

Group 50: Erythrocytes from HIV individuals treated with OMINF at $50 \mathrm{~g} / \mathrm{L}$.

Erythrocytes from seventeen HIV/AIDS-free male and female individuals were used to form the control group. Erythrocytes were treated in vitro in water bath at $37^{\circ} \mathrm{C}$ for one hour. Subsequently, samples were vortexed for erythrocyte hemolysis and centrifuged at $3600 \mathrm{rpm}$ for 15 minutes to remove the supernatant and enable the analytical determinations. 


\subsubsection{Analytical Determinations}

\section{(1) Determining Thiobarbituric Acid Reactive Substances (TBARS)}

TBARS were measured according to the protocol described by Stocks and Dormandy (1971). The supernatant was added, along with the reaction mixture of trichloroacetic acid (TCA), to $28 \%(\mathrm{v} / \mathrm{v})$ thiobarbituric acid (TBA) at concentration $0.1 \mathrm{~mol} / \mathrm{L}$, at $95{ }^{\circ} \mathrm{C}$. Readings were performed at $532 \mathrm{~nm}$. Results were expressed as $\eta \mathrm{mol}$ $\mathrm{MDA} / \mathrm{g} \mathrm{Hb}$. Hemoglobin $(\mathrm{Hb})$ level analysis was conducted according to recommendations in the Labtest ${ }^{\mathbb{B}}$ commercial kit.

(2) Determining the Reduced Glutathione (GSH) Levels

The technique described by Ellman (1959) was used to determine the GSH levels using potassium phosphate buffer (TFK) at $1 \mathrm{M}, \mathrm{pH} 7.4$, and acid 5,5'-ditiobis-(2-nitrobenzoic) (DTBN). The procedure was performed in ice bath and the readings were conducted in visible spectrophotometer, at $412 \mathrm{~nm}$. Results were expressed as $\mu \mathrm{mol} \mathrm{GSH} / \mathrm{Hb}$. Hb level analysis was conducted according to recommendations in the Labtest ${ }^{\circledR}$ commercial kit.

(3) Determining the Carbonyl Protein (CP) Levels

CP level analyses were performed based on the technique described by Levine et al. (1990), using 10\% (v/v) of trichloroacetic acid (TCA), $2 \mathrm{~N}$ hydrochloric acid, $10 \mathrm{mM}$ of 2,4-Dinitrophenylhydrazine (DNPH) and $3 \%(\mathrm{~m} / \mathrm{v})$ of sodium dodecyl sulfate (SDS) in the reaction mixture. Readings were carried out in visible spectrophotometer, at $370 \mathrm{~nm}$. Results were expressed as $\eta \mathrm{mol} \mathrm{CPs} / \mathrm{mg}$ TPs. Total Protein (TP) level analysis was conducted

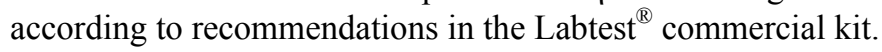

\subsubsection{Statistical Analysis}

The analytical determinations of all samples were performed in triplicate and results were expressed as $\pm \mathrm{SD}$ (Standard Deviation). The distribution of variables was subjected to the Kolmogorov-Smirnov, Shapiro-Wilk normality and D'Agostino-Person omnibus normality tests. Data concerning the same parameters of all studied groups were subjected to one-way analysis of variance (ANOVA), which was followed by Tukey-Kramer test. Significantly different rates were set at $\mathrm{p}<0.05$.

\section{Results}

\subsection{Extraction Yields}

The amount of $355.33 \mathrm{~g}$ fresh plant yielded $79.53 \mathrm{~g}$ of dry plant material, which was used to obtain $10.58 \mathrm{~g}$ of hydroethanolic extract (HET), it corresponded to $13.53 \%$ HET yield in comparison to the dry material.

\subsection{Phytochemical Screening Through Thin Layer Chromatography, Total Polyphenol, Flavonoid and Tannin Contents}

Table 1 presents results of phytochemical screening conducted through thin layer chromatography (TLC) and of spectrophotometric polyphenol, total flavonoid and tannin measurements.

TLC screening did not find alkaloids in the sample, although it recorded essential oil, saponins and terpenoids. Spectrophotometric measurements also showed polyphenolic substances, flavonoids and tannins.

Table 1. Results of phytochemical screening conducted through thin layer chromatography and spectrophotometric assays in order to determine the total amount of polyphenols, flavonoids and tannins in the Origanum majorana hydroethanolic extract

\begin{tabular}{lllll}
\hline \multicolumn{5}{c}{ TLC screening } \\
\hline \multirow{2}{*}{ Eluents } & $\begin{array}{l}\text { Toluene-ethylacetate } \\
(93: 7)\end{array}$ & $\begin{array}{l}\text { Chloroform-glacialaceticacid- } \\
\text { methanol-water (64:32:12:8) }\end{array}$ & $\begin{array}{l}\text { Toluene-ethylacetate- } \\
\text { diethylamine (70:20:10) }\end{array}$ & $\begin{array}{l}\text { Ethylacetate- } \\
\text { methanol-water (77:15:8) }\end{array}$ \\
\hline Evaluated parameters & Essential oils & Saponins & Alkaloids & Terpenoids \\
\hline Results & POS & POS & NEG & POS \\
\hline
\end{tabular}

TLC results were expressed as positive (POS) or negative (NEG).

\subsection{Free Radical Scavenging Activity and Reducing Power}

The hydroethanolic extract (HET) of O. majorona showed antioxidant activity in the 2,2-diphenyl-1picrylhydrazyl (DPPH) assay (Figure 1). According to the calculated IC 50 values, the HET result was comparable to the rutin and ascorbic acid standards, the IC 50 value was $37.42 \mathrm{mg} / \mathrm{mL}$. 


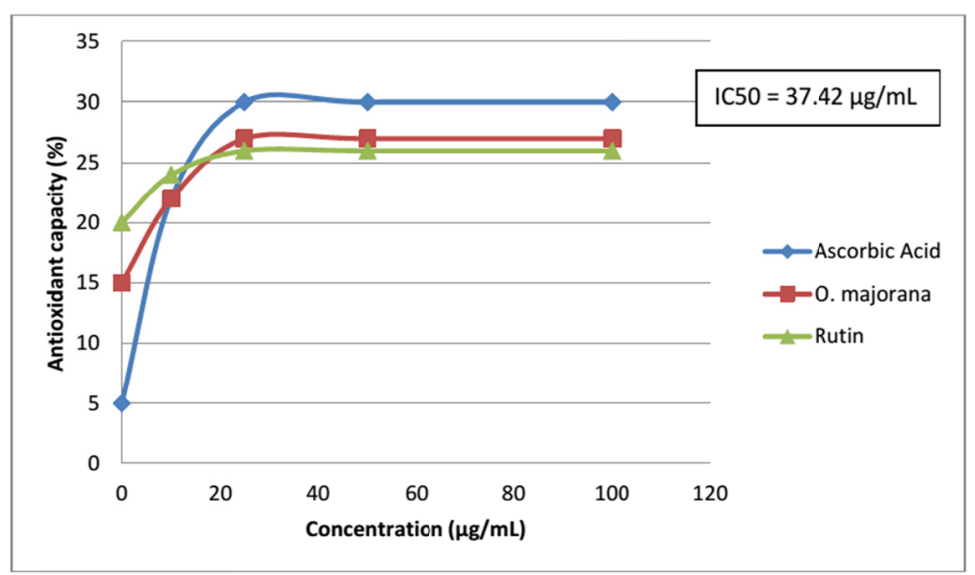

Figure 1. Antioxidant capacity rate of ascorbic acid and rutin standards, hydroethanolic extract and inhibitory concentration (IC 50) value of Origanum majorana evaluated through the DPPH method

Figure 2 shows the results of the ferric reducing antioxidant power (FRAP) assay. The extract was significantly different from the gallic acid standard only at concentration $1000 \mu \mathrm{g} / \mathrm{mL}(\mathrm{p}<0.05)$; it showed ferric reducing capacity equivalent to that of gallic acid at concentrations ranging from 25 to $500 \mu \mathrm{g} / \mathrm{mL}$.

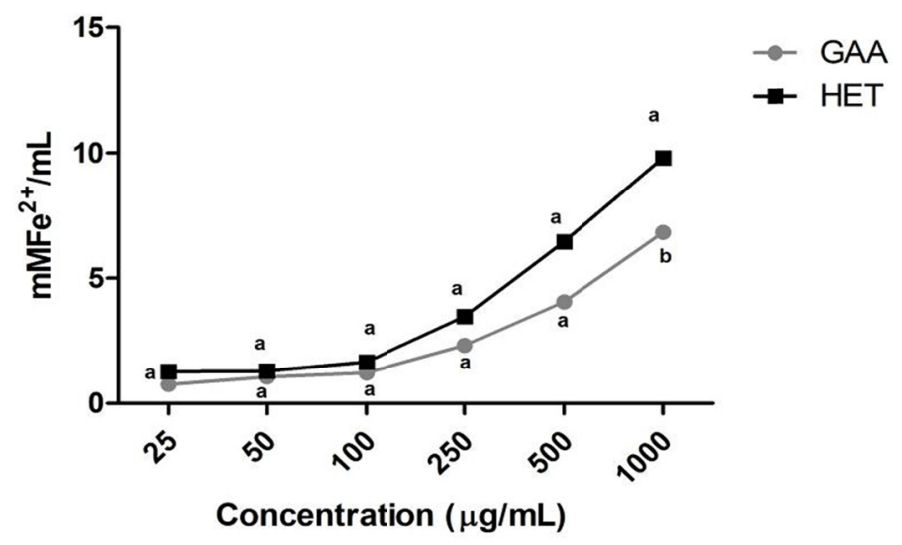

Figure 2. Ferric reducing antioxidant power of Origanum majorana hydroethanolic extract (HET) using gallic acid $(\mathrm{GAA})$ as standard. Different letters mean significant differences $(\mathrm{p}<0.05)$

3.4 Antioxidant Capacity of Origanum marjorana Infusion Analyzed Through Oxidative Stress Biomarkers in Erythrocytes of HIV-positive Individuals Based on the Determination of Thiobarbituric Acid-reactive Substances (TBARS), Reduced Glutathione (GSH) and Carbonylated Proteins

Figure 3 (A, B and C) shows the results of antioxidant assays applied to Origanum majorana infusion (OMINF) against oxidative stress biomarkers in erythrocytes of HIV-positive individuals. OMINF was able to significantly decrease MDA formation in the TBARS assay at all tested concentrations in comparison to the basal group - it also showed significant differences between groups: 10 to 50 and 25 to $50 \mathrm{~g} / \mathrm{L}^{-1}$ (Figure 3A). Figure 3B shows increased GSH at all tested concentrations in comparison to the basal group. The study revealed significantly decreased protein carbonyl levels after incubation at different extract concentrations $(10,25$ and $50 \mathrm{~g} / \mathrm{L})$, as shown in Figure 3C. 
A

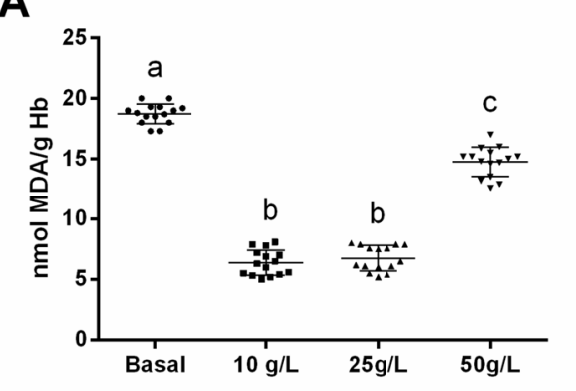

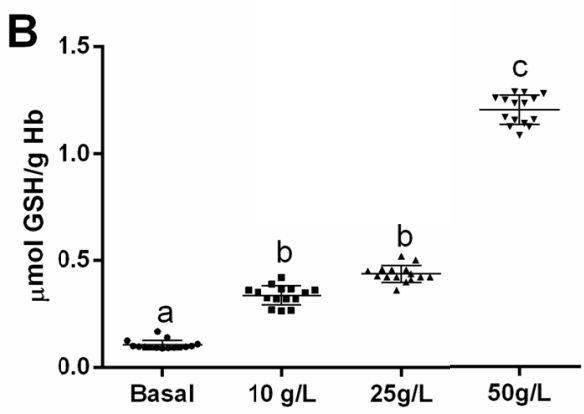

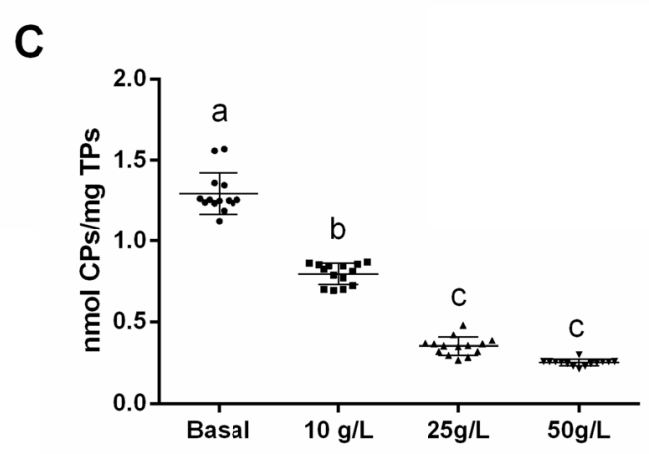

Figure 3. (A) TBARS levels ( $\eta$ mol MDA/g Hb); (B) GSH levels ( $\mu$ mol GSH/g Hb); (C) CPs levels ( $\eta \mathrm{mol}$ $\mathrm{CPs} / \mathrm{mg}$ TPs) in erythrocytes of HIV-positive patients exposed to Origanum marjorana infusion at concentrations 10, 25 and $50 \mathrm{~g} / \mathrm{L}$. Tukey's multiple comparison test was the analysis method of choice. Different letters mean significant differences $(\mathrm{p}<0.05)$

\section{Discussion}

TLC is often underestimated, although its application scope is methodologically simple and fast. It is also a sensitive and economical method used to evaluate secondary metabolites in natural products (Pascual, Carretero, Slowing, \& Villar, 2002). TLC screening results (Table 1) met previous reports about secondary metabolite classes in the literature (Edris et al., 2003; Shan et al., 2005; Wojdylo et al., 2007; Pimple et al., 2012; Chuang et al., 2018). Results demonstrated the presence of essential oil constituents, terpenoids and saponins in the HET extract, as well as lack of alkaloids. Determining constituent classes in crude extracts is essential to phytochemical investigations, as well as to subsequent trials focused on investigating their pharmacological potential (Pascual et al., 2002; Horn et al., 2015; Mori et al., 2017; Gelatti et al., 2018).

Total flavonoids, phenolic compounds and tannins in the samples were spectrophotometrically quantified (Table 1). Our results are quantitatively higher than the ones recorded in a previous phenological study with methanol extracts (Hamrouni-Sellami et al., 2009). Based on the clear relationship between antioxidant capacity and phenolic compound levels in a given sample (Krishnaiah, Sarbatly, \& Nithyanandam, 2011), it was suggested that the free radical scavenging activity presented by the herein tested extract (Figure 1) resulted from high phenol, flavonoid and tannin concentrations. In addition, the result of the FRAP assay (Figure 2) allowed inferring that HET can neutralize free radicals by working as electron donor to convert them into more stable products and to prevent the free radical chain reaction from happening (Pimple et al., 2012).

We tested the antioxidant activity of $O$. majorana infusion against erythrocytes of HIV-positive individuals undergoing antiretroviral therapy, based on the aforementioned potential of the species. It is known that HIV-positive patients present increased oxidative stress, mainly the ones undergoing antiretroviral therapy, which leads to increased lipid peroxidation. Studies found in the literature indicate that good nutrition and exogenous supplementation may help reducing oxidative stress rates (Gil et al., 2011; Masiá et al., 2017). The option we made for using infusion as extraction method simulates its use in many traditional medicine systems and provides a possible basis for its oral use. Results of all tested biomarkers showed significant difference between the basal and all treatment groups. Based on the TBARS assay, the greater the damage, the greater the MDA formation. The OMINF in our study decreased MDA production to basal levels; however, the best results were obtained at concentrations 10 and $25 \mathrm{~g} / \mathrm{L}$ (Figure 3A). In fact, plant extracts can present pro-oxidant or 
antioxidant behavior depending on the applied dose (Bonfanti et al., 2013). Lipid peroxidation is an oxidative deterioration process, in which polyunsaturated fatty acids are damaged by radical species. MDA is one of the most widely used biomarkers, since it is one of the secondary products of lipid peroxidation (Brum et al., 2013) - high MDA levels can indicate oxidative damages to mitochondrial and hepatocyte cell membranes. The TBARS assay is capable of estimating the oxidative damage in cell membranes due to its high sensitivity, although it lacks specificity to distinguish products formed during lipid peroxidation (Duarte et al., 2016). Overall, changes in MDA levels can be a signature of changes in membrane physiology-OMINF protects against this physiological unbalance, mainly at concentrations 10 and $25 \mathrm{~g} / \mathrm{L}$. The inhibition measured in the TBARS assay suggested that it was linked to phenolic compound levels.

Additionally, GSH levels increased significantly at the $50 \mathrm{~g} / \mathrm{L}$ dose of OMINF infusion (Figure 3B). Glutathione (as neuronal antioxidant) plays an important role in $\mathrm{H}_{2} \mathrm{O}_{2}$ detoxification and helps preventing damages to macromolecules caused by oxidative stress (McBean, 2017). Glutathione is found in reduced (GSH) and oxidized (GSSG) forms, but the reduced form prevails in healthy cells. GSH depletion can activate neuronal lipoxygenase, which, in its turn, can generate increased intracellular peroxide levels through arachidonic acid catabolism (Boadi, Harris, Anderson, \& Adunyah, 2013). The subsequent oxidative damage resulting from $\mathrm{H}_{2} \mathrm{O}_{2}$ and hydroxyl radicals $\left(\mathrm{OH}^{-}\right)$may play a key role in the neuronal dysfunction and/or death of patients affected by neurodegenerative diseases. Thus, GSH plays a vital role in combating oxidative stress in cells.

Our study recorded significant decrease in the carbonylated protein assay, after incubation at different OMINF concentrations (10, 25 and $50 \mathrm{~g} / \mathrm{L}$ ); these results showed dose-dependent effect (Figure 3C), in which higher concentrations had better effect than the lower ones. This behavior could be explained by the higher amount of phenolic compounds in the highest doses. This result was already expected, since O. majorana has shown high polyphenolic compound levels to which we attributed the antioxidant properties of the investigated plant species. With respect to the action of oxidant stressors over proteins, it is known that they increase the formation of carbonyl groups (Horn et al., 2015); such formation may also result from the harmful effect of substances like hypochlorous acid and monodicarbonyls (such as MDA). However, unlike lipid peroxidation, protein oxidation is not featured by chain reactions. Measuring the level of carbonyl groups in circulating proteins provides advantages that other oxidative stress markers do not provide; these oxidation products form relatively early, besides being more stable; thus, they can be useful oxidative stress markers (Brum et al., 2013). High protein carbonyl group levels have been observed in several diseases, such as Alzheimer's disease, rheumatoid arthritis, diabetes, sepsis, chronic renal failure and in some malignancies (Kamdem et al., 2013).

Based on the herein presented data, the best activity level versus basal group results of TBARS, GSH and carbonylated protein tests were recorded at plant extract concentrations $10 \mathrm{~g} / \mathrm{L}$ in TBARS and $50 \mathrm{~g} / \mathrm{L}$ in the other tests. This outcome indicated that the plant extract worked through different protection mechanisms. Again, these promising results of significantly reduced oxidative stress marker levels suggested that $O$. majorana performs an important antioxidant activity, which can be explained by its secondary metabolite content, mainly by its high antioxidant compound content. The lowest concentration was particularly effective in the TBARS test, besides being known as lipid peroxidation marker.

The antioxidant properties of $O$. majorana were previously studied by Erenler et al. (2016). However, the antioxidant activity of its infusion against the erythrocytes of HIV-positive individuals was first described in our study. Apparently, the treatment with OMINF in vitro helped better protecting the erythrocytes. Glutathione peroxidase is applied to metabolic pathways associated with the detoxification of organic and inorganic peroxides, since its action depends on the GSH content in phase II biotransformation reactions to prevent damages to cell membranes and to other macromolecules (Horn et al., 2015). It was possible inferring that the OMINF infusion enhanced the use of GSH as substrate by erythrocytes, which may have decreased the formation of carbonylated proteins and TBARS. We hypothesize that the infusion can achieve sufficient plasma levels to produce biological effects in studies conducted in vivo, so studies with pharmacokinetic models should be encouraged. Alternatively, out study opens windows for research involving specific formulations of the herein adopted extract, since it showed good antioxidant compound concentration.

\section{References}

Abdel-Massih, R. M., Fares, R., Bazzi, S., El-Chami, N., \& Baydoun, E. (2010). The apoptotic and anti-proliferative activity of Origanum majorana extracts on human leukemic cell line. Leukemia Research, 34, 1052-1056. https://doi.org/ 10.1016/j.leukres.2009.09.018

Benzie, I. F., \& Strain, J. J. (1996). The ferric reducing ability of plasma (FRAP) as a measure of "antioxidant power": the FRAP assay. Analytical Biochemistry, 239, 70-76. https://doi.org/ 10.1006/abio.1996.0292 
Bhatia, S., Shukla, R., Madhu, S. V., Gambhir, J. K., \& Prabhu, K. M. (2003). Antioxidant status, lipid peroxidation and NO end products in patients of type 2 diabetes mellitus with nephropathy. Clinical Biochemistry, 36, 557-562. https://doi.org/10.1016/S0009-9120(03)00094-8

Boadi, W. Y., Harris, S., Anderson, J. B., \& Adunyah, S. E. (2013). Lipid peroxides and glutathione status in human progenitor mononuclear (U937) cells following exposure to low doses of nickel and copper. Drug and Chemical Toxicology, 36, 155-162. https://doi.org/10.3109/01480545.2012.660947

Bonfanti, G., Bitencourt, P. R., Bona, K. S., Silva, P. S., Jantsch, L. B., Pigatto, A. S., ... Moretto, M. B. (2013). Syzygium jambos and Solanum guaraniticum show similar antioxidant properties but induce different enzymatic activities in the brain of rats. Molecules, 18, 9179-9194. https://doi.org/10.3390/molecules 18089179

Brum, T. F., Zadra, M., Piana, M., Boligon, A. A., Fröhlich, J. K., de Freitas, R. B., ... Athayde, M. L. (2013). HPLC Analysis of Phenolics Compounds and Antioxidant Capacity of Leaves of Vitex megapotamica (Sprengel) Moldenke. Molecules, 18, 8342-8357. https://doi.org/10.3390/molecules18078342

Chandra, S., \& De Mejia, G. E. (2004). Polyphenolic compounds, antioxidant capacity and quinone reductase activity of an aqueous extract of Ardisia compressa in comparison to Mate (Ilex paraguaiensis) and Green (Camellia sinensis) Teas. Journal of Agriculture and Food Chemistry, 52, 3583-3589. https://doi.org/ $10.1021 / \mathrm{jf0352632}$

Choi, C. W., Kim, S. C., Hwang, S. S., Choi, B. K., Ahn, H. J., Lee, M. Y., .. Kim, S. K. (2002). Antioxidant activity and free radical scavenging capacity between Korean medicinal plants and flavonoids by assay-guided comparison. Plant Science, 163, 1161-1168. https://doi.org/10.1016/S0168-9452(02)00332-1

Chuang, L. T., Tsai, T. H., Lien, T. J., Huang, W. C., Liu, J. J., Chang, H., .. Tsai, P. J. (2018). Ethanolic Extract of Origanum vulgare Suppresses Propionibacterium acnes-Induced Inflammatory Responses in Human Monocyte and Mouse Ear Edema Models. Molecules, 23(8), 1-11. https://doi.org/10.3390/molecules230 81987

Duarte, A. E., Waczuk, E. P., Roversi, K., da Silva, M. A. P., Barros, L. M., Cunha, F. A. B., ... Burger, M. E. (2016). Polyphenolic composition and evaluation of antioxidant activity, osmotic fragility and cytotoxic effects of Raphiodon echinus (Nees \& Mart.) Schauer. Molecules, 21, 1-15. https://doi.org/10.3390/ molecules21010002

Edris, A. E., Shalaby, A., \& Fadel, H. M. (2003). Effect of organic agriculture practices on the volatile aroma components of some essential oil plants growing in Egypt II: sweet marjoram (Origanum majorana L.) essential oil. Flavor and Fragrance Journal, 18, 345-351. https://doi.org/10.1002/ffj.1235

Elansary, H. O., Abdelgaleil, S. A. M., Mahmoud, E. A., Yessoufou, K., Elhindi K., \& El-Hendawy, S. (2018). Effective antioxidant, antimicrobial and anticancer activities of essential oils of horticultural aromatic crops in northern Egypt. BMC Complementary and Alternative Medicine, 18, 1-10. https://doi.org/10.1186/s12906018-2262-1

Ellman, G. L. (1959). Tissue sulfhydryl groups. Archives of Biochemistry and Biophysics, 82, $70-77$. https://doi.org/10.1016/0003-9861(59)90090-6

Erenler, R., Sem, O., Aksit, H., Demirtas, I., Yaglioglu, A. S., Elmastas, M., \& Telci, İ. (2016). Isolation and identification of chemical constituents from Origanum majorana and investigation of antiproliferative and antioxidant activities. Journal of the Science of Food and Agriculture, 96, 822-836. https://doi.org/10.1002 /jsfa. 7155

Gelatti, G. T., Tissiani, A. C., Mayer, M. S., Felippin, T., Gewehr, D. M., Koefender, J., ... Horn, R. C. (2018). In Vitro Antioxidant Potential of Baccharis trimera and Baccharis articulata Infusions in Postmenopausal Women. International Journal for Innovation Education and Research, 6, 99-112. https://doi.org/10.31686/ ijier.Vol6.Iss6.1060

Gil, L., Tarinas, A., Hernández, D., Riverón, B. V., Pérez, D., Tápanes, R., ... Pérez, J. (2011). Altered oxidative stress indexes related to disease progression marker in human immunodeficiency virus infected patients with antiretroviral therapy. Biomedicine \& Pharmacoterapy. https://doi.org/10.1016/j.biopha.2010.09.009

Hafez, A. A. (2012). Physico-Chemical and sensory properties of cakes supplemented with different concentration of marjoram. Australian Journal of Basic and Applied Sciences, 6, 463-470. 
Hamrouni-Sellami, I., Maamouri, E., Chahed, T., Wannes, W. A., Kchouk, M. E., \& Marzouk, B. (2009). Effect of growth stage on the content and composition of the essential oil and phenolic fraction of sweet marjoram (Origanum majorana L.). Industrial Crops and Products, 30, 395-402. https://doi.org/10.1016/j.indcrop. 2009.07.010

Handl, S., Hellweg, P., Khol-parisini, A., Rossmann, B., Thurner, K., Luf, W., Novak, J., \& Zentek, J. (2008). Effect of oregano (O. majorana $\times O$. vulgare) on performance and antioxidative capacity of quails fed a diet rich in omega3 fatty acids. Journal of Animal Physiology and Animal Nutrition (Berl), 92, 242-245. https://doi.org/10.1111/j.1439-0396.2007.00731.x

Horn, R. C., Soares, J. C., Mori, N. C., Gelatti, G. T., Manfio, C. E., Golle, D. P., ... Oliveira, C. (2015). Antioxidant Effect of Physalis peruviana Fruit Aqueous Extract-The Antioxidant Effect of Physalis. Journal of Agricultural Science, 7, 137-143. https://doi.org/10.5539/jas.v7n12p137

Kamdem, J. P., Adeniran, A., Boligon, A. A., Klimaczewski, C. V., Elekofehinti, O. O., Hassan, W., ... Athayde, M. L. (2013). Antioxidant activity, genotoxicity and cytotoxicity evaluation of lemon balm (Melissa officinalis L.) ethanolic extract: Its potential role in neuroprotection. Industrial Crops and Products, 51, 26-34. https://doi.org/10.1016/j.indcrop.2013.08.056

Krishnaiah, D., Sarbatly, R., \& Nithyanandam, R. (2011). A review of the antioxidant potential of medicinal plant species. Food Bioproducts Processing, 89, 217-233. https://doi.org/10.1016/j.fbp.2010.04.008

Levine, R. L., Garland, D., Oliver, C. N., Amici, A., Climent, I., Lenz, A. G., \& Stadtman, E. R. (1990). Determination of carbonyl content in oxidatively modified proteins. Methods in Enzymology, 186, 464-478. https://doi.org/10.1016/0076-6879(90)86141-H

Masiá, M., Padilla, S., Fernández, M., Barber, X., Moreno, S., Iribarren, J. A., ... Gutiérrez, F. (2017). Contribution of Oxidative Stress to Non-AIDS Events in HIV-Infected Patients. Journal of Acquired Immune Deficiency Syndromes, 75(2), 36-44. https://doi.org/10.1097/QAI.0000000000001287

McBean, G. J. (2017). Cysteine, Glutathione, and Thiol Redox Balance in Astrocytes. Antioxidants, 6(3), 1-13. https://doi.org/10.3390/antiox6030062

Mori, N. C., Horn, R. C., Oliveira, C., Gelatti, G. T., Klafke, J. Z., Tissiani, A. C., .. Micheloti, B. T. (2017). Journal of Agricultural Science, 9, 68-77. https://doi.org/10.5539/jas.v9n9p68

Morrison, I. M., Asiedu, E. A., Stuchbury, T., \& Powel, A. A. (1995). Determination of Lignin and Tannin contents of cowpea seeds coats. Annals of Botany, 76, 287-290. https://doi.org/10.1006/anbo.1995.1097

Novak, J., Langbehn, J., Pank, F., \& Franz, C. M. (2002). Essential oil compounds in historical sample of marjoram (Origanum majorana Lamiaceae). Flavor and Fragrance Journal, 17, 175-180. ,https://doi.org/ 10.1002/ffj.1077

Oniga, I., Puscas, C., Silaghi-Dumitrescu, R., Olah, N. K., Sevastre, B., Marica, R., ... Hanganu, D. (2018). Origanum vulgare ssp. vulgare: Chemical Composition and Biological Studies. Molecules, 23(8), 2-14. https://doi.org/10.3390/molecules23082077

Park, J. B. (2011). Identification and quantification of a major anti-oxidant and anti-inflammatory phenolic compound found in basil, lemon thyme, mint, oregano, rosemary, sage, and thyme. International Journal of Food Science and Nutrition, 62, 577-584. https://doi.org/10.3109/09637486.2011.562882

Pascual, M. E., Carretero, M. E., Slowing, K. V., \& Villar, A. (2002). Simplified Screening by TLC of Plant Drugs. Pharmaceutical Biology, 40, 139-143. https://doi.org/10.1076/phbi.40.2.139.5849

Peuchant, E., Brun, J., Rigalleau, V., Dubourg, L., Thomas, M., \& Daniel, J. (2004). Oxidative and antioxidative status in pregnant women with either gestational or type 1 Diabetes. Clinical Biochemistry, 37, 293-298. https://doi.org/10.1016/j.clinbiochem.2003.12.005

Pimple, B. P., Kadam, P. V., \& Patil, M. J. (2012). Ulcer healing properties of different extracts of Origanum majorana in streptozotocin-nicotinamide induced diabetic rats. Asian Pacific Journal of Tropical Disease, 2, 312-318. https://doi.org/10.1016/S2222-1808(12)60068-1

Ramadan, G., El-Beih, N. M., Arafa, N. M. S., \& Zahra, M. M. (2013). Preventive effects of egyptian sweet marjoram (Origanum majorana L.) leaves on haematological changes and cardiotoxicity in isoproterenol-treated albino rats. Cardiovascular Toxicology, 13, 100-109. https://doi.org/10.1007/s12012 $-012-9189-4$ 
Roby, M. H. H., Sarhan, M. A., Selim, K. A. H., \& Khalel, K. I. (2013). Evaluation of antioxidant activity, total phenols and phenolic compounds in thyme (Thymus vulgaris L.), sage (Salvia officinalis L.), and marjoram (Origanum majorana L.) extracts. Indrial Crops and Products, 43, 827-831. ,https://doi.org/10.1016/j.in dcrop.2012.08.029

Shan, B., Cai, Y. Z., Sun, M., \& Corke, H. (2005). Antioxidant capacity of 26 spice extracts and characterization of their phenolic constituents. Journal of Agricural and Food Chemistry, 53, 7749-7759. https://doi.org/10. 1021/jf051513y

Stocks, J., \& Dormandy, T. L. (1971). The autoxidation of human red cell induced by hydrogen peroxide lipids. British Journal of Haematology, 20, 95-111. https://doi.org/10.1111/j.1365-2141.1971.tb00790.x

Wagner, H., \& Bladt, S. (1996). Plant Drug Analysis (2nd ed.). Berlim. Springer-Verlag. https://doi.org/10.1007/ 978-3-642-00574-9

Woisky, R. G., \& Salatino, A. (1998). Analysis of propolis: some parameters and procedures for chemical quality control. Journal of Apicultural Research, 37, 99-105. https://doi.org/10.1080/00218839.1998.11100961

Wojdylo, A., Oszmianski, J., \& Czemerys, R. (2007). Antioxidant activity and phenolic compound in 32 selected herbs. Food Chemistry, 105, 940-949. https://doi.org/10.1016/j.foodchem.2007.04.038

Yazdanparast, R., \& Shahriyary, L. (2008). Comparative effects of Artemisia dracunculus, Satureja hortensis and Origanum majorana on inhibition of blood platelet adhesion, aggregation and secretion. Vascular Pharmacology, 48, 32-37. https://doi.org/10.1016/j.vph.2007.11.003

\section{Copyrights}

Copyright for this article is retained by the author(s), with first publication rights granted to the journal.

This is an open-access article distributed under the terms and conditions of the Creative Commons Attribution license (http://creativecommons.org/licenses/by/4.0/). 